\title{
Justification of the amino acid composition of sunflower proteins for dietary and functional products
}

\section{Mykola Oseyko' ${ }^{1}$, Tetiana Romanovska ${ }^{1}$, Vasyl Shevchyk ${ }^{2}$}

\author{
1 - National University of Food Technologies, Kyiv, Ukraine \\ 2 - "Vasyl Shevchyk's eye microsurgery," Chernihiv, Ukraine
}

\section{Keywords:}

Sunflower

Press cake

Grist

Protein

Amino acid

Functional.

\section{Article history:}

Received 21.05.2019

Received in revised form 18.01.2020

Accepted 30.06.2020

Corresponding author:

Mykola Oseyko

E-mail:

nikios@ukr.net

DOI: $10.24263 / 2304-$

974X-2020-9-2-11

\section{Abstract}

Introduction. The study of samples of sunflower kernel processing was carried out to substantiate the amino acid composition of proteins for dietary and functional products.

Materials and methods. The subject of the study is the samples of press cake, grist, and flour, and their amino acid composition and physicochemical parameters. The amino acid composition of the samples was determined using liquid chromatograph Dionex ICS-3000 with an electrochemical detector. The ratio of hydrophobic and hydrophilic amino acids was studied in the samples.

Results and discussion. It was found that the protein content in flour from sunflower kernels is $22 \%$ higher. The content of essential amino acids is $31.1 \%$ higher than in the press cake from which the flour was isolated. The increase in protein content in sunflower flour is due to the increase of the fine fraction during fractionation. Along with the increase in total protein content, flour is enriched with essential hydrophobic amino acids, in particular leucine $(14.2 \%)$, isoleucine $(6.7 \%)$, methionine $(11.2 \%)$, as well as replaceable hydrophobic proline (10.5\%). Limiting amino acid in flour is lysine (score $78 \%$ ), the content of other essential amino acids significantly exceeds their content in the ideal protein (score of leucine 153\%, isoleucine 143\%, methionine $213 \%$, methionine with cystine $258 \%$, phenylalanine and tyrosine $177 \%$ ). The content of leucine and isoleucine in the classic kinds of sunflower is limited. In sunflower kernel flour, their content is exceeded one and a half times. To balance the obtained sunflower flour by lysine content, it is rational to use its compositions with other lysine-containing types of flour from oilseeds and / or with the use of food microbiological lysine.

Conclusion. Balanced protein-lipid eco-products and drugs on the basis of complex processing of sunflower seeds show functional and technological properties and contribute to disease prevention. 


\section{- Food Technology -}

\section{Introduction}

Samples of processed sunflower seeds are studied to substantiate the amino acid composition of proteins for dietary and functional products.

Aspects of the protein problem in the world. Protein is crucial in a balanced diet for people of all ages [1,2]. Protein deficiency in food can affect the health of the population.

According to [3], nine out of ten Indians do not have sufficient protein intake. Most people in the United States and Canada find it almost impossible not to meet their protein needs. (Hamilton et al., 1991).

Dr. Geoff's review [4] presents protein concentrations in food. Energy consumption from the maximum protein requirement for adults is approximately $8 \%$ of the estimated average energy requirement. These values represent something similar to the concentration of protein in food. A diet with a protein concentration of about $8 \%$ should be adequate for adults (for children, this figure is close to 5\%). We consume only a limited number of food products in which at least $8 \%$ of calories are attributed to protein. In particular, human milk, which is an ideal food for fast-growing children, is one such product. Oil proteins and modified or processed oil proteins can be included in food to give it nutritional value and functional properties. Vegetable protein processing includes physicochemical and heat treatment, which affects the nutritional value of manufactured products, as well as technical features. Conversely, functional properties $\backslash$ affect the behavior of the protein during processing and storage. These properties can be changed by chemical and enzymatic treatment [5].

The use of balanced protein-lipid eco-products and drugs in the systemic concept of health (KTIOL ${ }^{\circledR}$ system) contributes to disease prevention, comprehensive recovery and health improvement. It is advisable to use the KTIOL $®$ system for disease prevention and rehabilitation for people of all ages $[6,7]$.

It is important not only to find available sources of protein-containing food syrups but also to create products that are safe and balanced in the chemical composition of nutrients $[8$, 9].

An important component of food is a protein with a balanced composition of essential amino acids [10].

Current trends in food technology are the search for new sources of protein and improving the technological processes of processing materials. It is important to study the methods of obtaining protein from the available sources, oilseeds, in particular, striving for the preservation and balance of essential amino acids [11,12

The problem of obtaining protein is the presence in the raw material of natural substances that adversely affect the quality of the extracted protein, or complicate the processing of raw materials [13].

Of particular interest is the production of dietary and functional foods from sunflower seed kernels [14-17].

Technological aspects of amino acids in proteins. At the same time, the treatment of oilseeds for lipid extraction, including heating, compression and removal, changes the inherent protein, functional and technological properties, as well as affects its digestibility [18-22].

Essential amino acids must be present in proteins, and their balance in a protein determines the biological value of a food product. For cereals, lysine is a restrictive essential amino acid, and for legumes - methionine and cysteine, which contain sulfur. At the same time, limited critical amino acids are thermosensitive and reactive, so that any treatment will affect their content in the resulting product. The oxidation of sulfur-containing amino acids 


\section{— Food Technology —}

could also pose a difficulty. Also, hydroperoxides of fatty acids react with amino acids to form sulfoxides. After the interaction of hydroperoxides with methionine, methionine sulfoxide is detected, which has no biological significance. Lysine and methionine are isomerized in alkaline media, and their D-isomers are not biologically valuable. The Maillard reaction involving the same free amino acids, reducing the carbohydrate content when heated, gives a compound consisting of radical reagents such as fructose-L-tryptophan, which reduces the digestibility of free amino acids. The products of the Maillard reaction to toxicity have been studied because it has been found that in animals such substances slow down growth [23].

The difficulty of assessing the native protein is the impossibility of its direct detection. There are methods by which you can indirectly determine the degree of influence of technological processing on the nature of the protein. All of them are based on a comparison of the characteristics of the raw and processed protein. In particular, determining the activity of certain enzymes, protein composition for solubility in water, solutions of salts, acids and alkalis, digestibility of proteins in certain species of animals or birds, and determining the metabolic energy of feed for them [10, 24-26].

Proteins consist of 20 amino acids, eight of which are needed. Amino acids differ in their physical and chemical properties, in particular thermal stability [27, 28], reactivity [22], polarity and hydrophilicity. The hydrophilicity of an amino acid is affected by the presence of radicals and their properties that are not bound by a peptide bond [30].

Proteins are hydrophilic and can absorb up to $200 \%$ of water to dry weight. There may be hydrophobic areas, most of which are in the middle of the protein molecule. The hydrophilicity or hydrophobicity of certain parts of the protein is determined by the amino acid radicals that remain after the formation of peptide bonds [30].

Of the eight essential amino acids, only two - lysine and threonine - have hydrophilic properties, and the other six - hydrophobic. In the presence of polar groups, there are amino acids that can carry a positive charge: lysine, arginine and histidine. Tyrosine and cysteine have radicals that can take a negative charge. Asparagine, glutamine, serine and threonine have nonionic polar radicals [31]. Usually, the constituent components determine the properties of the substance. Therefore, it is important to find an experimental correlation between the content of hydrophilic and hydrophobic amino acids in the protein and between the modes of technological processes of protein production [15, 30].

The purpose of our study was to investigate sunflower kernel flour and materials for its production, as well as the ratio of hydrophobic and hydrophilic amino acids in these products.

\section{Materials and methods}

The subject of the study is the products from the sunflower seed kernels, including flour, press cake and grist.

\section{Materials}

The flour from the sunflower seed kernels was obtained by crushing the kernel, further pressing the material at a temperature of 100-105 C, thus obtaining the press cake [15]. The press cake was used as a raw material for the flour. The press cake was milled and fractionated through a sieve. The fraction of passage through a sieve with apertures $0.3-0.6$ $\mathrm{mm}$ was selected. The grist was obtained by degreasing the press cake with hexane in a laboratory extraction plant $[15,32]$. At the same time, three swabs of sunflower flour were 


\section{- Food Technology —}

taken: for preparing the sample for chromatographic analysis, to determine the moisture content, and to determine the residual content of the oil.

Sample preparation for determining the amino acid content. The amino acid composition and physicochemical of processed sunflower seed kernels were studied for flour, press cake and grist.

The sample preparation for determining the amino acid composition was carried out by acid hydrolysis of the sample [7]. The flour was placed in an ampoule tube and added 1:1 by weight $6 \mathrm{n}$. $\mathrm{HCl}$. The ampoule was sealed and kept at $110{ }^{\circ} \mathrm{C}$ for 24 hours. After hydrolysis, the contents of the ampule were filtered, the filtrate was evaporated in a water bath. The dry residue was dissolved in a citrate buffer, filtered again and used for analysis.

\section{Methods}

The amino acid composition of the protein in sunflower flour, the press cake and grist was determined chromatographically. The amino acid composition of the prepared samples was determined using a liquid chromatograph Dionex ICS-3000 with an electrochemical detector [7]. The presence of amino acid was determined by the time it was released from the column, having previously calibrated it with pure amino acids. The number of amino acids was determined by the area of the release peak of certain amino acids. The signal from the detector is processed by a computer program that automatically determines the contents of each amino acid in the sample.

In the sunflower flour, the press cake and the grist, the moisture content was determined by an arbitration method [30] by drying to a constant mass at a temperature of $105{ }^{\circ} \mathrm{C}$; residual oil content was measured using the Soxhlet method, and the total protein content measured by the Kjeldahl method.

\section{Study results analysis}

The change in amino acid content in sunflower flour was calculated for the content of the respective amino acid in the press cake, that was the source for the flour. The ratio between hydrophobic and hydrophilic amino acids in the studied samples was also calculated.

\section{Results and discussion} (shrot)

Study of amino acid content of the sunflower flour, the press cake and the grist

Sunflower flour is a thin homogeneous powder of gray color in appearance with a distinct taste and smell of sunflower kernel [15]. In the sunflower grist from the purified seed, the residual oil content was $14.3 \pm 0.4 \mathrm{wt} . \%$, the moisture content of $6.22 \pm 0.24 \mathrm{wt} . \%$. The standard deviation of the amino acid content of the flour, the press cake, and the grist was $4.8 \%$.

Tables 1 and 2 show the amino acid composition of sunflower products from the sunflower kernel compared with the literature on the content of amino acids of the press cake and grist sunflower. 
Table 1

Amino acid (AA) content of the sunflower flour, the press cake and the grist (shrot), \% wt

\begin{tabular}{|c|c|c|c|c|c|c|}
\hline \multirow[t]{2}{*}{$\mathbf{N}$} & \multirow{2}{*}{$\begin{array}{l}\text { Amino acids } \\
\text { (AA) }\end{array}$} & \multicolumn{5}{|c|}{ Flour from the sunflower seed kernels } \\
\hline & & Flour & $\begin{array}{c}\text { Score } \\
\text { (account by } \\
\text { AA) flour, \% }\end{array}$ & $\begin{array}{c}\text { Increase in AA } \\
\text { content in flour, } \% \\
\text { wt. from the } \\
\text { contents of the } \\
\text { press cake }\end{array}$ & $\begin{array}{l}\text { Press } \\
\text { cake }\end{array}$ & Grist \\
\hline & $\begin{array}{l}\text { Essential } \\
\text { amino acids: }\end{array}$ & 18,30 & & & 13,96 & 13,87 \\
\hline & hydrophobic & 14,63 & & & 10,96 & 10,65 \\
\hline 1 & Valine (V) & 2,61 & 132 & & 2,15 & 1,80 \\
\hline 2 & Isoleucine (I) & 2,27 & 143 & 6,7 & 1,78 & 1,50 \\
\hline 3 & Leucine (L) & 4,26 & 153 & 14,1 & 3,25 & 3,57 \\
\hline 4 & Methionine (M) & 2,11 & 213 & 11,2 & 1,31 & 1,59 \\
\hline 5 & Tryptophan (W) & - & & & - & - \\
\hline \multirow[t]{2}{*}{6} & $\begin{array}{l}\text { Phenylalanine } \\
\text { (F) }\end{array}$ & 3,38 & 284 & 12,7 & 2,47 & 2,19 \\
\hline & hydrophilic & 3,67 & & & 3,00 & 3,22 \\
\hline 7 & Lysine $(\mathrm{K})$ & 1,71 & 78 & & 1,52 & 1,52 \\
\hline \multirow[t]{3}{*}{8} & Threonine $(\mathrm{T})$ & 1,96 & 124 & & 1,48 & 1,70 \\
\hline & $\begin{array}{l}\text { Non-essential } \\
\text { amino acids: }\end{array}$ & 21,40 & & & 18,57 & 18,49 \\
\hline & hydrophobic & 8,56 & & & 6,80 & 6,89 \\
\hline 9 & Alanine (A) & 2,54 & & & 2,04 & 2,08 \\
\hline 10 & Glycine $(\mathrm{G})$ & 2,90 & & & 2,42 & 1,93 \\
\hline 11 & Proline $(\mathrm{P})$ & 2,96 & & 10,5 & 2,21 & 2,77 \\
\hline \multirow[t]{2}{*}{12} & Cystine (C) & 0,16 & & & 0,13 & 0,11 \\
\hline & hydrophilic & 12,84 & & & 11,77 & 11,60 \\
\hline 13 & Arginine (R) & 5,50 & & & 5,93 & 5,41 \\
\hline 14 & $\begin{array}{l}\text { Aspartic acid } \\
\text { (D) }\end{array}$ & 0,95 & & & 0,78 & 0,89 \\
\hline 15 & Histidine $(\mathrm{H})$ & 1,13 & & & 0,87 & 0,75 \\
\hline 16 & $\begin{array}{l}\text { Glutamic acid } \\
\text { (E) }\end{array}$ & 1,86 & & & 1,52 & 1,81 \\
\hline 17 & Serine $(\mathrm{E})$ & 2,56 & & 9,0 & 1,92 & 1,92 \\
\hline \multirow[t]{2}{*}{18} & Tyrosine (Y) & 0,84 & & & 0,75 & 0,82 \\
\hline & $\begin{array}{l}\text { Total } \\
\text { number of }\end{array}$ & 39,70 & & 22,0 & 32,53 & 32,36 \\
\hline
\end{tabular}

During the processing of sunflower seeds, the prepared material is subjected to wet heat treatment, so it is possible to break covalent bonds and proteins [15]. Chemical interactions with other substances are possible between amino acids and proteins [13]. As a result, they lose their properties and undergo chemical transformations. Therefore, the content of amino acids in the grist decreases compared to the cake, and this trend is maintained for all amino acids. 
The preparation of flour from the press cake requires grinding at the micro-level, and probably the peptide and covalent bonds in the protein molecules are preserved. This is confirmed by the fact [15] that the amount of protein in flour increases and the bonds between other components (cellulose, minerals, lignin) are destroyed faster than in protein molecules, which allows us to obtain a fraction enriched in protein. Logically, the enrichment of the product with protein is due to an increase in the content of amino acids in sunflower flour obtained from the cake.

\section{Comparative analysis of amino acid content of sunflower flour, the press cake and the grist}

Experimental studies (Table 2) confirm the increase in the content of amino acids in sunflower flour compared to the press cake, which was the raw material for the production of flour.

It was found that sunflower kernel flour has a higher total protein content and a higher content of essential amino acids than in the cake from which it was obtained. In the flour from the purified kernel found a limited content of the amino acid lysine (78\%), the content of other essential amino acids significantly exceeds their content in the ideal protein (leucine $153 \%$, isoleucine $143 \%$, methionine $213 \%$, methionine in the amount of cystine $158 \%$, phenylalanine $284 \%$ phenylalanine in the amount of tyrosine $177 \%$ ). The content of leucine and isoleucine in the sunflower of classical processing is limited [25], in sunflower flour from the purified kernel their content exceeds one and a half times. Improving the composition of sunflower flour is provided by the introduction of food additives that have a higher content of amino acids, which is limited to flour [26].

The protein content of cake and meal is lower than the protein content of the flour, which is due to the enrichment of the protein fraction of fine particles during fractionation. Along with the increase in total protein content, the fine fraction is enriched with essential hydrophobic amino acids, in particular, leucine, isoleucine, and methionine. Also, the content of the substituted amino acids alanine, glycine, proline, which are hydrophobic, and the hydrophilic amino acids serine and histidine increases.

\section{Content of hydrophobic and hydrophilic amino acids and their ratio in sunflower products}

The calculated ratio of hydrophobic and hydrophilic amino acids in sunflower products from the purified kernel is given in Table 3.

Sunflower cake and meal are obtained by heat treatment in the presence of hydrophobic reagents. Fractionation of crushed cake particles promotes the concentration of protein in sunflower flour and increases the content of hydrophobic amino acids.

As a result of fractionation, the content of hydrophobic amino acids and the content of total protein in sunflower flour increased in comparison with cake and meal.

The ratio of hydrophobic amino acids to hydrophilic amino acids showed that the content of hydrophobic amino acids increases, and the number of hydrophilic amino acids decreases. This indicates that free radicals, which are not involved in the formation of the peptide bond in the protein, are better able to resist the processing during oil production and the production of sunflower flour than the hydrophilic amino acids (Table 3). 
Table 2

Comparative analysis of amino acid (AA) content of sunflower flour, the press cake and the grist (shrot), \% wt

\begin{tabular}{|c|c|c|c|c|c|c|}
\hline $\mathbf{N}$ & $\begin{array}{l}\text { Amino acids } \\
\text { (AA) }\end{array}$ & $\begin{array}{c}\text { Sunflower } \\
\text { press cake } \\
{[22]}\end{array}$ & $\begin{array}{c}\text { Sunflower } \\
\text { press cake } \\
{[20]}\end{array}$ & $\begin{array}{l}\text { Sunflower } \\
\text { grist [14] }\end{array}$ & $\begin{array}{c}\text { Sunflower } \\
\text { grist [21] }\end{array}$ & $\begin{array}{c}\text { Sunflower } \\
\text { grist [21] }\end{array}$ \\
\hline & $\begin{array}{l}\text { Essential } \\
\text { amino acids: }\end{array}$ & 8,60 & 7,03 & & & \\
\hline & hydrophobic & & & & & \\
\hline 1 & Valine (V) & 1,32 & 1,23 & 3,83 & 1,96 & 2,00 \\
\hline 2 & Isoleucine (I) & \multirow{2}{*}{2,73} & \multirow{2}{*}{2,44} & 3,26 & 1,26 & 1,64 \\
\hline 3 & Leucine (L) & & & 7,40 & 2,28 & 2,54 \\
\hline 4 & $\begin{array}{l}\text { Methionine } \\
(\mathrm{M})\end{array}$ & 0,71 & 0,51 & $2,38^{\square}$ & 0,93 & 0,91 \\
\hline 5 & $\begin{array}{l}\text { Tryptophan } \\
\text { (W) }\end{array}$ & - & - & 1,22 & - & - \\
\hline \multirow[t]{2}{*}{6} & $\begin{array}{l}\text { Phenylalanine } \\
\text { (F) }\end{array}$ & 1,41 & 0,92 & $8,17^{\square \square}$ & 1,75 & 1,84 \\
\hline & hydrophilic & & & & & \\
\hline 7 & Lysine (K) & 1,09 & 0,86 & 3,75 & 1,34 & 1,43 \\
\hline \multirow[t]{3}{*}{8} & Threonine (T) & 1,34 & 1,07 & 4,85 & - & - \\
\hline & $\begin{array}{l}\text { Non-essential } \\
\text { amino acids: }\end{array}$ & 13,43 & 12,63 & & & \\
\hline & hydrophobic & & & & & \\
\hline 9 & Alanine $(\mathrm{A})$ & 1,35 & 1,25 & & - & - \\
\hline 10 & Glycine $(\mathrm{G})$ & 1,81 & 1,48 & & - & - \\
\hline 11 & Proline $(\mathrm{P})$ & 1,45 & 1,54 & & - & - \\
\hline \multirow[t]{2}{*}{12} & Cystine (C) & - & - & & - & - \\
\hline & hydrophilic & & & & & \\
\hline 13 & Arginine (R) & 1,91 & 1,83 & & 3,23 & 3,14 \\
\hline 14 & $\begin{array}{l}\text { Aspartic acid } \\
\text { (D) }\end{array}$ & - & - & & - & - \\
\hline 15 & Histidine $(\mathrm{H})$ & 0,89 & 0,59 & & 0,85 & 1,01 \\
\hline 16 & $\begin{array}{l}\text { Glutamic acid } \\
\text { (E) }\end{array}$ & 3,93 & 4,22 & & - & - \\
\hline 17 & Serine $(E)$ & 1,31 & 1,11 & & - & - \\
\hline \multirow[t]{2}{*}{18} & Tyrosine $(\mathrm{Y})$ & 0,78 & 0,61 & & - & - \\
\hline & $\begin{array}{l}\text { The total } \\
\text { number of }\end{array}$ & 22,03 & 19,66 & 34,86 & 13,60 & 14,51 \\
\hline
\end{tabular}

- Methionine + Cystine, ${ }^{\square}$ - Phenylalanine + Tyrosine 
Table 3

Content of hydrophobic and hydrophilic amino acids and their ratio in sunflower products

\begin{tabular}{|c|c|c|c|c|c|}
\hline \multirow[t]{2}{*}{ Indicator } & \multicolumn{3}{|c|}{$\begin{array}{c}\text { Products from sunflower } \\
\text { kernel }\end{array}$} & \multirow{2}{*}{$\begin{array}{c}\text { Sunflower } \\
\text { press cake } \\
{[15]}\end{array}$} & \multirow{2}{*}{$\begin{array}{c}\text { Sunflower } \\
\text { press cake } \\
{[13]}\end{array}$} \\
\hline & Flour & $\begin{array}{l}\text { Press } \\
\text { cake }\end{array}$ & $\begin{array}{c}\text { Grist } \\
\text { (shrot) }\end{array}$ & & \\
\hline $\begin{array}{l}\text { Content of essential } \\
\text { amino acids (EA) }\end{array}$ & 18.30 & 13.96 & 13.87 & 8.60 & 7.03 \\
\hline hydrophobic & 14.63 & 10.96 & 10.65 & 6.17 & 5.10 \\
\hline hydrophilic & 3.67 & 3.00 & 3.22 & 2.43 & 1.93 \\
\hline $\begin{array}{ll}\text { The ratio of } \\
\text { hydrophobic } & \text { to } \\
\text { hydrophilic EA } & \\
\end{array}$ & 3.99 & 3.65 & 3.31 & 2.54 & 2.64 \\
\hline $\begin{array}{l}\text { The content of } \\
\text { substitutable amino } \\
\text { acids (SA) }\end{array}$ & 21.40 & 18.57 & 18.49 & 13.43 & 12.63 \\
\hline hydrophobic & 8.40 & 6.67 & 6.78 & 4.61 & 4.27 \\
\hline hydrophilic & 13.00 & 11.90 & 11.71 & 8.82 & 8.36 \\
\hline $\begin{array}{l}\text { Ratio of hydrophobic } \\
\text { to hydrophilic }\end{array}$ & 0.65 & 0.56 & 0.58 & 0.52 & 0.51 \\
\hline $\begin{array}{l}\text { Total content of } \\
\text { hydrophobic amino } \\
\text { acids }\end{array}$ & 23,03 & 17,63 & 17,42 & 10,78 & 9,37 \\
\hline $\begin{array}{l}\text { Total content of } \\
\text { hydrophilic amino } \\
\text { acids }\end{array}$ & 16,67 & 14,90 & 14,93 & 11,25 & 10,29 \\
\hline $\begin{array}{ll}\text { The ratio } & \text { of } \\
\text { hydrophobic } & \text { to } \\
\text { hydrophilic } & \\
\end{array}$ & 1,38 & 1,18 & 1,17 & 0,96 & 0,91 \\
\hline
\end{tabular}

This property of proteins to retain functional hydrophobic properties during the technological processing of press cake, flour, and grist allows us to use these products as raw bio materials for the production of dietary and functional protein-containing and protein-lipid products and to improve their quality.

\section{Conclusion}

1. The balanced amino acid composition of sunflower flour is substantiated.

2. An increase in the content of hydrophobic amino acids improves the technological properties of flour. It is advisable to use sunflower kernel as a formulation component for the development and introduction of dietary and functional products with improved consumer properties, as well as for expanding the range of food products and improving their quality.

3. Balanced protein-lipid eco-products and drugs on the basis of complex processing of sunflower seeds show functional and technological properties and contribute to disease prevention. 


\section{References}

1. Carpenter K.J. (1994), Protein and energy: a study of changing ideas in nutrition, Cambridge University Press, Cambridge

2. Webb G.P. (2012), Nutrition: maintaining and improving health. $4^{\text {th }}$ edition, Taylor and Francis, Oxford

3. Times of India (2015), Nine out of ten Indians lack proper protein intake, Avialable at: http://timesofindia.indiatimes.com/city/nagpur/Nine-out-of-10-Indians-lackproper-protein-intake/articleshow/47534086.cms.

4. Dr Geoff (2016) The Protein Gap - one of the biggest errors in nutritional science. Overview, Avialable at: https://drgeoffnutrition.wordpress.com/2016/12/07/theprotein-gap-one-of-the-biggest-errors-in-nutritional-science/ Dr. Geoff / December 7, 2016

5. Andre's Mourea, J. Sineirob, Herminia Domı'ngueza, Juan Carlos Parajo'a (2006), Functionality of oilseed protein products: A review, Avialable at: https://www.academia.edu/20956984/Functionality_of_oilseed_protein_products_A _review.

6. Mykola Oseyko, Vasyl Shevchyk, Olena Pokryshko (2019), Antimicrobial and antifungal activity of model drugs on the basis of food plant extracts in the systemic concept of health, Ukrainian Journal of Food Science, 7(1), pp. 70-82 DOI: 10.24263/2310-1008-2019-7-1-9.

7. Mykola Oseyko, Nataliia Sova, Maryna Lutsenko, Viktoriia Kalyna (2019), Chemical aspects of the composition of industrial hemp seed products // Ukrainian Food Journal, 8(3), pp. 544-559, DOI: 10.24263/2304- 974X-2019-8-3-11.

8. Oseyko M., Romanovska T., Shevchyk V. (2017), Funktsionalnyy Produkt v kontseptsiyi endoekolohiyi zdorovya (Functional products in endoecology health concepts), Scientific Works of NUFT, 23(3), pp. 192-203.

9. Tutel'yan V.A., Vyalkov A.I., Razumov A.N., Mixajlov V.I., Moskalenko K.A., Odinec A.G., Sbezhneva V.G., Sergeev V.N. (2010), Nauchnye osnovy zdorovogo pitaniya, Moscow.

10. Gonzalez-Perez S., Vereijken J.M. (2007), Sunflower proteins: an overview of their physicochemical, structural, and functional properties, J. Sci. Food Agric., 87(12), pp. 2173-2191.

11. Salgado P.R., Molina Ortiz S.E., Petruccelli S. et al. (2011), Sunflower protein concentrates and isolates prepared from oil cakes have high water solubility and antioxidant capacity, J. Am. Oil Chem. Soc., 88(3), pp. 351-360.

12. Shirokoryadova O.V., Minakova A.D., Shherbakov V.G., Logunova O.V. (2008), Bioximicheskie osobennosti belkovykh fraktsiy iz semyan podsolnechnika, Izvestiya vuzov. Pishhevaya tekhnologiya, 1, pp. 23-24.

13. Nosenko T. (2017), Comparison of biological value and technological properties of oilseed proteins, Ukrainian Food Journal, 6(2), pp. 226-238.

14. Labeyko M.A., Lytvynenko O.A., Fedyakina Z.P., Petik P.F. (2012), Otrymannya bilkovoho produktu z nasinnya sonyashnyku vitchyznyanoyi selektsiyi, Visnyk Nats. tekhn. un-tu "KhPI", 39, pp. 117-124, Available at: http:// archive.kpi.kharkov.ua/files/18128/

15. Oseiko N.I. (2006), Tekhnolohiia roslynnykh olii, Varta, Kyiv. 
16. Kamsulina N.V., Skurikhina L.A., Hubal L.M. Doslidzhennia funktsionalnotekhnolohichnykh vlastyvostei bilkiv iz nasinnia soniashnyku, Prohresyvni tekhnika ta tekhnolohii kharchovykh vyrobnytstv restorannoho hospodarstva $i$ torhivli: $z b$. nauk. pr., 2(22), pp. 50-61, Available at:

http://elib.hduht.edu.ua/jspui/handle/123456789/589

17. Fadeev L.V. (2013), Podsolnechnik Ukrainy - sehodnia i zavtra, Spetsemm, Kyiv.

18. Sitohy M.Z., Badr E.H., Perifanova-Nemska M., Khadjiskf T.S. (1993), Characterization of enzymatically extracted sunflower seed oil as well as the protein residues, Grasas y Aceites, 44(6), pp. 345-347.

19. Villanueva A., Vioque J., Sanchez-Vioque R., Clemente A., Bautista J., Millan F. (1999), Production of an extensive sunflower protein hydrolysate by sequential hydrolysis with endo- and exo-proteases, Grasas y Aceites, 50(6), p. 472-476.

20. Nikolaev S.I., Dikusarov V.G., Randelin D.A. i dr. (2016), Sravnitelnyy analiz khimicheskogo sostava produktov pererabotki semyan maslichnykh kultur, Nauchnyj zhurnal KubGAU, 118(04), available at: http://ej.kubagro.ru/2016/04/pdf/106.pdf

21. Nikolaev S.I., Karapetyan A.K., Kornilova E.V. i dr. (2015), Sravnitelnyy analiz aminokislotnogo sostava kormov, Nauchnyj zhurnal KubGAU, 107(03), Available at: http://ej.kubagro.ru/2015/03/pdf/110.pdf

22. Nikolaev S.I., Karapetyan A.K., Chekhranova S.V. i dr. (2016), Sravnitelnyy analiz khimicheskogo sostava produktov pererabotki semyan maslichnykh kultur, Nauchnyj zhurnal KubGAU, 118(04), Available at: http://ej.kubagro.ru /2016/04/pdf/83.pdf

23. Flaumenbaum B.L., Tanchev S.S., Grishin M.A. (1986), Osnovy konservirovaniya pischevyikh produktov, Moscow.

24. Ivanova P., Chalova V., Koleva L., Pishtiyski I. (2013), Amino acid composition and solubility of proteins isolated from sunflower meal produced in Bulgaria, International Food Research Journal, 20(6), pp. 2995-3000.

25. Gonzalez-Vega J.C., Stein H.H. (2015), Amino acid digestibility in canola, cottonseed, and sunflower products fed to finishing pigs, J. Anim. Sci., 20, pp. 43914400 .

26. Nenova N., Drumeva M. (2012), Investigation on protein content and amino acid composition in the kernels of some sunflower lines, Helia, 35(56), pp. 41-46.

27. González-Pérez S., Vereijken J.M., Merck K.B. et al. (2004), Conformational states of sunflower (Heliantus annuus) Heliantinin: effect of heat and pH, J. Agric. Food Chem., 52(22), pp. 6770-6778.

28. Molina M.I., Petruccelli S., Anon M.C. (2004), Effect of pH and ionic strength modifications on thermal denaturation of the $11 \mathrm{~S}$ globulin of sunflower (Helianthus annuus), J. Agric. Food Chem., 52(19), pp. 6023-6029.

29. Nicolson S., Human H. (2013), Chemical composition of the 'low quality' pollen of sunflower (Helianthus annuus, Asteraceae), Apidologie, Springer Verlag, 44(2), p.144-152.

30. Romanovska T.I. (2006), Fizyko-khimichni aspekty kharchovykh tekhnolohiy, Naukova dumka, Kyiv.

31. Hans-Dieter Jakubke, Hans Jeschkeit (1982). Aminosäuren, Peptide, Proteine, Akademie-Verlag, Berlin.

32. Cristina Popovici (2013), Soxhlet extraction and characterisation of natural compounds from walnut (Juglans regia L.) by-products, Ukrainian food journal, 2(3), pp. 328-336

33. Oseyko M. (1987), Bilkovo-lipidni dobavky, Zerno i khlib, 4, p. 31. 